\title{
PELAKSANAAN KEWENANGAN PENAHANAN \\ TERHADAP DEBITOR PAILIT MENURUT \\ UU RI NO 37 TAHUN 2004 TENTANG KEPAILITAN DAN PKPU
}

\author{
Oleh Jimmy Simanjuntak \\ jimmys.juntak@gmail.com \\ Universitas Kristen Indonesia
}

\begin{abstract}
The Indonesian Criminal Code Procedure (KUHAP) provides fundamental legal basis in conducting detention, in concern that the suspect/defendant shall conduct escapement, erasure or destruction of the evidence, or shall conduct recidivism. Law Number 37 of 2004 regarding Bankruptcy and Suspension of Debt Payment Obligation also regulates regarding Detentions towards Bankrupt Debtors on the obligations as Bankrupt Debtors in providing important information/details towards the Administrators, Supervisory Judge, or the Administrators Members concerning the Debtors assets which then shall be managed and settled as bankruptcy assets; however this does not cover the mechanism for detention undertook by the Public Prosecutor evidently appointed by the Supervisory Judge.
\end{abstract}

\section{Keyword: kewenangan penahanan terhadap debitor pailit}

\section{Pendahuluan}

Putusan pernyataan pailit membawa akibat hukum terhadap debitor. Salah satu konsekuensi hukum yang cukup fundamental adalah debitor yang semula berwenang mengurus dan menguasai hartanya menjadi tidak berwenang mengurus dan menguasai hartanya, terhitung sejak pukul 00.00 dari hari putusan pailit diucapkan. ${ }^{2}$ Dalam putusan pernyataan pailit, Pengadilan Niaga juga menyatakan penunjukan seorang hakim pengawas dari hakim niaga pengadilan dan pengangkatan seorang kurator. Sejak tanggal putusan pernyataan pailit diucapkan, yang berhak berkuasa atas harta pailit debitor adalah kurator. ${ }^{3}$ Walaupun debitor pailit telah kehilangan hak untuk mengurusi harta pailitnya, namun debitor tetap harus ikut serta jika diperlukan dalam pemberesan dan pengurusan harta pailit, misalnya perlunya kerjasama debitor pailit dalam memberikan keterangan dengan jelas dan benar kepada kurator

\footnotetext{
${ }^{1}$ Dosen tetap Fakultas Hukum Universitas Kristen Indonesia.

2 Lihat Pasal 24 UU No. 37 Tahun 2004 Tentang Kepailitan dan PKPU.

${ }^{3}$ Pasal 1 ayat (1) UU No. 37 Tahun 2004 Tentang Kepailitan dan PKPU
}

dalam melakukan pencatatan (inventarisasi) harta (boedel) pailit, kedatangannya ke Pengadilan Niaga apabila dipanggil oleh hakim pengawas, dan/atau hadir dalam rapat kreditor yang telah ditetapkan.

Suatu proses pengurusan dan pemberesan harta pailit, sangat ditentukan oleh peranan debitor pailit. Jika debitor kooperatif, proses akan berjalan dengan baik dan lancar, tetapi sebaliknya jika debitor tidak menunjukkan itikad baik untuk bekerja sama, proses pengurusan dan pemberesan harta pailit akan berjalan lama dan bahkan bisa tidak berhasil.

Dalam Undang-Undang Nomor 37 Tahun 2004 tentang Kepailitan dan Penundaan Kewajiban Pembayaran Utang (UUKPKPU), hal ini telah diantisipasi dengan adanya ketentuan yang mengatur untuk bisa menahan debitor pailit yang tidak kooperatif. ${ }^{4}$ Penahanan merupakan suatu pranata hukum untuk mencegah debitur tidak memenuhi kewajibannya sekaligus memastikan pelaksanaan proses pemberesan harta (boedel) pailit berjalan secara adil bagi semua pihak. Peraturan mengenai

\footnotetext{
${ }^{4}$ M. Hadi Subhan, 2015, Hukum Kepailitan, Prinsip Norma dan Praktik di Peradilan, Kecana Prenadamedia Group, Jakarta, hlm.179
} 
penahanan terhadap debitor pailit yang tidak kooperatif diatur dalam Pasal 93, 94, 95, 96, 97, 98, 110 dan 121 Undang-Undang Nomor 37 Tahun 2004 tentang Kepailitan dan PKPU. ${ }^{5}$

Ketentuan Pasal 93 ayat (1), Pengadilan dengan putusan pernyataan pailit atau setiap waktu setelah itu, atas usul Hakim Pengawas, permintaan Kurator, atau atas permintaan seorang Kreditor atau lebih dan setelah mendengar Hakim Pengawas, dapat memerintahkan supaya Debitor Pailit ditahan, baik ditempatkan di Rumah Tahanan Negara maupun di rumahnya sendiri, di bawah pengawasan jaksa yang ditunjuk oleh Hakim Pengawas sebagaimana disebutkan dalam Pasal 93 ayat (2), Perintah penahanan sebagaimana dimaksud pada ayat (1) dilaksanakan oleh jaksa yang ditunjuk oleh Hakim Pengawas. Kemudian dalam Pasal 95 menyatakan permintaan untuk menahan Debitor Pailit yang tidak kooperatif harus dikabulkan sebagaimana dimaksud dalam Pasal 98, Pasal 110 ayat (1) Debitor Pailit wajib menghadap Hakim Pengawas, Kurator, atau panitia kreditor apabila dipanggil untuk memberikan keterangan dan/atau Pasal 121 ayat (1) Debitor Pailit wajib hadir sendiri dalam rapat pencocokan piutang, agar dapat memberikan keterangan yang diminta oleh Hakim Pengawas mengenai sebab musabab kepailitan dan keadaan harta pailit, ayat (2) mengatur Kreditor dapatmemintaketerangandari Debitor Pailitmengenai hal-hal yang dikemukakan melalui Hakim Pengawas. Namun, kenyataannya dalam kasus Kepailitan di mana debitor telah dinyatakan pailit, belum ada satu pun putusan mengenai penahanan debitor pailit untuk melaksanakannya. Pada prakteknya terdapat permasalahan pelaksanaan ketentuan Pasal 93 ayat (1) dan (2) UUKPKPU mengenai perintah yang menyebutkan penahanan dilakukan oleh Jaksa berdasarkan perintah atau penetapan dari Pengadilan, dalam penjelasan Undang-Undang Nomor 37 Tahun 2004 tentang Kepailitan dan PKPU tidak menjelaskan jaksa mana yang diberi kewenangan untuk melakukan penahanan mengingat lembaga kejaksaan sendiri terdiri dari lembaga kejaksaan negeri, kejaksaan tinggi dan kejaksaan agung. Kitab Undang -Undang Hukum Acara Pidana (KUHAP) telah mengatur tentang penahanan terhadap seseorang yang diduga melakukan tindak pidana, jika dikaitkan dengan pelaksanaan penahanan yang ditentukan oleh UndangUndang Nomor 37 Tahun 2004 tentang Kepailitan dan PKPU yang merupakan ranah kepailitan dimana sengketa yang di permasalahkan terkait penyelesaian pembayaran utang-piutang, sudah tepatkah atau apakah dapat dipersamakan alasan penahanan yang dimaksud UUKPKPU mencegah debitor agar memenuhi kewajibannya, dengan ketentuan penahanan dalam ketentuan KUHAP? Perdebatan pro-kontra penahanan berkisar seputar persyaratan formal dan persyaratan material penahanan. Di satu sisi, penegak hukum (Kepolisian, Kejaksaan dan Hakim) melakukan penahanan beralaskan persyaratan yang ditentukan dalam KUHAP dalam ranah pidana dan Undang-Undang Nomor 37 Tahun 2004 tentang Kepailitan dan PKPU dalam ranah perdata. Persoalan ini sesungguhnya yang sedang dihadapi dalam pelaksanaan penahanan dan kewenangan siapa yang menahan? Hal ini menandakan ketentuan, penahanan seorang debitor pailit berdasarkan UUKPKPU perlu diteliti lebih lanjut dan serta kejelasan mengenai kewenangan kejaksaan mana yang berwenang melaksanakan perintah UUKPKPU agar dapat memberikan kepastian hukum dalam proses pemberesan harta pailit. Bagaimana pengaturan penahanan dalam ketentuan Undang-Undang Nomor 37 tahun 2004 tentang Kepailitan dan PKPU dikaitkan dengan ketentuan penahanan dalam KUHAP, Bagaimana kewenangan jaksa dalam melakukan penahanan berdasarkan Undang-Undang Nomor 37 Tahun 2004 tentang kepailitan dan PKPU. Untuk mengetahui pengaturan penahanan dalam ketentuan Undang-Undang Nomor 37 tahun 2004 tentang Kepailitan dan PKPU dikaitkan dengan ketentuan penahanan dalam KUHAP. Untuk mengetahui dasar kewenangan jaksa dalam melakukan penahanan beradasarkan UndangUndang Nomor 37 Tahun 2004 tentang kepailitan dan PKPU.

\section{Pembahasan}

\section{Lembaga Penahanan (Gijzeling)}

Penerapan Lembaga Penahanan (Gijzeling) dalam Undang-Undang Nomor 37 Tahun 2004 tentang Kepailitan dan PKPU diatur dalam Pasal 93 UU Kepailitan yang intinya memberikan kewenangan kepada pengadilan untuk memerintahkan agar debitor pailit ditahan. Upaya Penahanan juga diatur khusus, lembaga penahanan (gijzeling) merupakan salah satu 
lembaga yang dikenal dalam hukum untuk proses penegakan hukum. Penegakan hukum melalui lembaga penahanan secara umum di bidang hukum perdata dapat dilihat di PERMA Nomor 1 Tahun 2000 tanggal 30 Juni tahun 2000 tentang Lembaga Paksa Badan. Ada dua hal yang patut dicermati dalam PERMA Nomor 1 Tahun 2000 ini, yaitu: ${ }^{6}$

1. Gijzeling sebagai suatu alat paksa eksekusi yang secara psikis diberlakukan terhadap debitur untuk melunasi hutang pokok.

2. Gijzeling sebagai upaya paksa tidak langsung dengan memasukkan seorang debitur nakal ke dalam rumah tahanan negara yang ditetapkan pengadilan. Debitor nakal dimaksud adalah penjamin utang yang dapat diperluas penunggak pajak yang mampu tetapi tidak mau membayar utangnya.

Beberapa substansi penting dalam PERMA tersebut antara lain pengecualian penerapan paksa badan kepada debitor pailit yang tidak beriktikad baik yang berusia 75 tahun; paksa badan hanya dapat diterapkan untuk debitor yang beriktikad tidak baik yang memiliki utang sekurang-kurangnya $\mathrm{Rp} 1$ milyar. Sebelum UU Kepailitan. Lembaga Paksa Badan atau Gijzeling juga diatur dalam beberapa aturan di ranah hukum perdata warisan Belanda yakni Pasal 209-224 Het Herziene Indonesisch Reglement (HIR) dan Pasal 242-258 Rechtsreglement voor de Buitengewesten (Rbg), serta Pasal 580-606 Reglement op de Burgerlijke Rechtsvordering (Rv).

Lembaga Paksa Badan atau Gijzeling juga dikenal dalam hukum perpajakan. Dasar hukumnya adalah UU Nomor 19 Tahun 1997 tentang Penagihan Pajak Dengan Surat Paksa sebagaimana diubah dengan UU Nomor 19 Tahun 2000. Hanya saja, istilah yang digunakan adalah "penyanderaan" yakni tindakan terhadap penanggung pajak yang mempunyai utang pajak minimal $\mathrm{Rp} 100$ juta dan diragukan iktikad baiknya.

\section{Penahanan Menurut KUHAP}

Upaya paksa merupakan kewenangan yang dimiliki oleh penyidik, penyidik pembantu dan penyelidik untuk melaksanakan tugas dan wewenangnya terhadap tersangka pelaku suatu tindak pidana. Sebagai suatu 'upaya paksa' harus dipahami bahwa upaya-upaya tersebut hanya akan

\footnotetext{
${ }^{6}$ Mulyasi W. Gizeling dalam Perkara Pajak, http://eprints. undip.ac.id /15739/1 / Mulyatsih_Wahyumurti.pdf, diakses pada tanggal 19 Mei 2019.
}

dilakukan oleh penyelidik, penyidik pembantu dan penyidik dalam 'keadaan terpaksa'. Upaya-upaya paksa tidak perlu dilakukan oleh penyelidik, penyidik pembantu dan penyidik apabila dianggap belum atau tidak mengganggu tugasnya untuk melakukan penyelidikan atau penyidikan. Upaya paksa itu terdiri dari penangkapan, penahanan, penggeledahan (penggeledahan badan dan penggeledahan rumah), penyitaan dan pemeriksaan surat. Penahanan dan penangkapan merupakan dua hal yang berbeda tetapi sulit dipisahkan. Tindakan penahanan selalu (sering) didahului dengan tindakan penangkapan, bahkan pelaksanaan penangkapan yang dapat dilakukan selama satu kali 24 jam tidak ada bedanya dengan penahanan. Penangkapan adalah suatu tindakan penyidik berupa pengekangan sementara waktu kebebasan tersangka atau terdakwa apabila terdapat cukup bukti guna kepentingan penyidikan atau penuntutan dan atau peradilan dalam hal serta menurut cara yang diatur dalam KUHAP (Pasal 1 butir 20 KUHAP). Apabila penangkapan dilakukan oleh penyelidik, di samping Surat Perintah Penangkapan, harus ada Surat Perintah Tugas. ${ }^{7}$ Akibat penangkapan sama dengan penahanan adalah hilangnya kebebasan seorang tersangka, dan oleh karena itu KUHAP memberikan pembatasan untuk melakukannya.

Pelaksanaan upaya paksa penahanan bukan hal yang mudah penanganannya, karena berkaitan dengan kebebasan seseorang, yang berarti pula akan menyentuh hak-hak asasi manusia. KUHAP telah mengatur tentang penahanan, namun di dalam pelaksanaannya tidaklah semudah yang diperkirakan. Pelaksanaan penahanan tidak mudah karena bersinggungan dengan hak kebebasan/ kemerdekaan sebagai hak asasi manusia yang harus dihormati. Penahanan seharusnya dilakukan jika sangat diperlukan, sebab kekeliruan melakukan penahanan akan berakibat pada tuduhan pelanggaran hak asasi manusia dan dapat dituntut melalui praperadilan ataupun pembayaran ganti kerugian. ${ }^{8}$ Hanya karena untuk kepentingan penegakan hukum, hak-hak tersangka/terdakwa dengan sangat terpaksa dikorbankan, setidak-tidaknya untuk sementara waktu. ${ }^{9}$ Penahanan adalah penempatan tersangka atau

\footnotetext{
${ }^{7}$ Mabes Polri, 2000, Himpunan Bujuklak, Bujuklap, Bujukmin Proses Penyidikan Tindak Pidana, Departemen Hankam, Mabes Polri, Jakarta, hlm. 11.

${ }^{8}$ L. Sumartini, 1996, Pembahasan Perkembangan Pembangunan Hukum Nasional tentang Hukum Acara Pidana, BPHN Depkeh dan HAM RI, hlm. 38

${ }^{9}$ Djoko Prakoso, 1985, Eksistensi Jaksa di Tengah-Tengah Masyarakat, Ghalia Indonesia, Jakarta, hlm. 5.
} 
terdakwaditempattertentuolehpenyidikataupenuntut umum atau hakim dengan penetapannya dalam hal serta menurut cara yang diatur dalam KUHAP (Pasal 1 butir 21 KUHAP). Berdasarkan Pasal 1 butir 21 KUHAP dapat diketahui bahwa yang berhak untuk melakukan penahanan adalah penyidik, penuntut umum dan hakim (pada pengadilan negeri, pengadilan tinggi,mahkamah agung). Di samping memberikan kewenangan untuk melakukan penahanan, Pasal 7 ayat (1) huruf $\mathrm{j}$ KUHAP masih memberi wewenang kepada penyidik untuk melakukan tindakan lain menurut hukum yang bertanggungjawab. Pasal 7 ayat (1) huruf j KUHAP seolah-olah memberi keleluasaan bagi penyidik untuk bertindak sesuai kehendaknya dengan anggapan bahwa apa yang dilakukannya merupakan tindakan keharusan dan masih selaras dengan kewajibannya. ${ }^{10}$ Penahanan dilakukan untuk kepentingan proses pemeriksaan atau penyelesaian perkara. Oleh karena itu maka:

a. Penyidik atau penyidik pembantu atas pelimpahan wewenang dari penyidik melakukan penahanan untuk kepentingan penyidikan.

b. Penuntut umum melakukan penahanan untuk kepentingan penuntutan.

c. Hakim melakukan penahanan untuk kepentingan pemeriksaan perkara di pengadilan

Perintah penahanan atau penahanan lanjutan (dalam hal penahanan diperpanjang) dilakukan terhadap seorang tersangka atau terdakwa yang diduga keras melakukan tindak pidana berdasarkan bukti yang cukup, apabila dikhawatirkan bahwa tersangka atau terdakwa akan melarikan diri, merusak atau menghilangkan barang bukti dan atau me ngulangi tindak pidana. Alasan untuk melakukan penahanan adalah adanya kekhawatiran dari aparat penegak hukum yang berhak untuk menahan. Apabila pejabat yang bersangkutan (penyidik, penuntut umum, hakim) tidak khawatir bahwa tersangka atau terdakwa akan melarikan diri, merusak atau menghilangkan barang bukti atau mengulangi tindak pidana, maka tersangka/terdakwa tidak perlu ditahan. Pemeriksaan berlangsung tanpa penahanan, dan tersangka atau terdakwa akan dipanggil apabila diperlukan untuk kepentingan pemeriksaan. ${ }^{11}$

Menurut H. M. A. Kuffal, dengan berdasar kepada Pasal 1 butir 21 jo. Pasal 20 jo. Pasal 21 ayat (1) jo.

\footnotetext{
${ }^{10}$ M. Yahya Harahap, 2003, Pembahasan Permasalahan dan Penerapan KUHAP, Penyidikan dan Penuntutan, Sinar Grafika, Jakarta, hlm. 105.

${ }^{11}$ Berlian Simarmata, Pengawasan Terhadap Pelaksanaan Penahanan Menurut Kuhap Dan Konsep Ruu Kuhap, Mimbar Hukum Volume 23, Nomor 1, Februari 2011, Halaman 1 - 236
}

Pasal 21 ayat (4) KUHAP, ada 2 (dua) dasar untuk melakukan penahanan, yaitu: ${ }^{12}$

1. Dasar hukum/dasar obyektif, yang terdiri dari:

a. tindak pidana yang diancam dengan pidana penjara 5 (lima) tahun atau lebih.

b. tindak-tindak pidana sebagaimana disebutkan di dalam Pasal 21 ayat (4) huruf b.

2. Dasar kepentingan/dasar subyektif, yang terdiri dari:

a. Kepentingan penyidikan, penuntutan dan pemeriksaan di sidang pengadilan.

b. Adanya kekhawatiran bahwa tersangka atau terdakwa akan melarikan diri, merusak/ menghilangkan barang bukti dan/atau mengulangi tindak pidana.

Ada tiga macam jenis penahanan, yaitu penahanan rumah tahanan negara (Rutan), penahanan rumah, dan penahanan kota. Penentuan jenis penahanan yang akan ditetapkan kepada seorang tersangka atau terdakwa ditentukan oleh pejabat yang bersangkutan sesuai dengan tingkat pemeriksaan. Demikian juga mengenai pengalihan jenis penahanan dari jenis penahanan yang satu ke jenis penahanan yang lain, atau mengubah status penahanan, dari status ditahan menjadi dibebaskan dari penahanan (tidak ditahan), atau sebaliknya. Seorang tersangka/ter-dakwa ditahan ditingkatpenyidikanakantetapitidakditahanditingkat penuntutan atau pengadilan, dan sebaliknya. Hal ini sejalan dengan alasan dilakukannya penahanan, yaitu adanya 'kekhawatiran' bahwa tersangka/terdakwa akan melarikan diri, menghilangkan atau merusak barang bukti, dan/atau mengulangi tindak pidana. Atas dasar hal tersebut, dapat saja terjadi kekhawatiran itu ada pada penyidik, akan tetapi penuntut umum tidak mengkhawatirkannya, sehingga pada saat penyidikan tersangka ditahan akan tetapi setelah berkasnya dan tersangka dilimpahkan ke kejaksaan negeri (penuntut umum), si tersangka/terdakwa tidak dikenakan penahanan. Dapat juga terjadi bahwa pada awalnya penyidik khawatir bahwa tersangka akan melarikan diri dan/ atau merusak/menghilangkan barang bukti, dan/atau akan mengulangi tindak pidana sehingga dikenakan penahanan, akan tetapi dalam perjalanan pemeriksaan kekhawatiran itu menjadi hilang, sehingga si tersangka tidak ditahan lagi, demikian juga sebaliknya pada setiap tingkat pemeriksaan. ${ }^{13}$

\footnotetext{
${ }^{12}$ H. M. A. Kuffal, 2007, Penerapan KUHAP dalam Praktik Hukum, UMM Press, Malang, hlm. 70.

${ }^{13}$ Berlian Simarmata, Op. Cit, hlm. 197-198
} 
Penahanan Menurut Undang-Undang Nomor 37 Tahun 2004 tentang Kepailitan dan PKPU

Undang-Undang Nomor 37 Tahun 2004 ten- tang Kepailitan dan PKPU tidak mendefinisikan mengenai penahanan secara tersurat ketentuan Pasal 93 hanya menyebutkan penahanan debitor dapat diusulkan hakim pengawas, permintaan kurator, atau atas permintaan seorang kreditor atau lebih setelah mendengar hakim pengawas pengadilan dalam putusan pernyataan pailit atau setiap waktu setelah itu dapat memerintahkan supaya debitor pailit di tahan. Penahanan debitor pailit dilaksanakan jaksa yang ditunjuk oleh hakim pengawas. Masa penahanan berlaku paling lama 30 (tiga puluh) hari dapat memperpanjang masa penahanan setiap kali untuk jangka waktu paling lama 30 (tiga puluh) hari atas usul Hakim Pengawas atau atas permintaan Kurator atau seorang Kreditor atau lebih. ${ }^{14}$

Pasal 95 menyatakan Penahan debitor wajib dikabulkan oleh hakim niaga, dengan alasan bahwa debitor pailit tidak koperatif dalam membantu kurator melakukan pemberesan harta pailit, seperti yang dalam ketentuan Pasal 98 yang menyebutkan sejak mulai pengangkatannya, Kurator harus melaksanakan semua upaya untuk mengamankan harta pailit dan menyimpan semua surat, dokumen, uang, perhiasan, efek, dan surat berharga lainnya dengan memberikan tanda terima. Artinya kurator harus diberikan semua daftar serta dokumen mengenai aset yang dimiliki oleh debitor pailit. Hal ini juga dipertegas dalam ketentuan Pasal 110 ayat (1) Debitor Pailit wajib menghadap Hakim Pengawas, Kurator, atau panitia kreditor apabila dipanggil untuk memberikan keterangan dan ayat (2) Dalam hal suami atau istri dinyatakan pailit, istri atau suami yang dinyatakan pailit wajib memberikan keterangan mengenai semua perbuatan yang dilakukan oleh masing-masing terhadap harta bersama. Ada kewajiban yang harus dipenuhi oleh debitor untuk memberikan informasi maupun keterangan mengenai harta pailit. Serta ketentuan Pasal 121 ayat (1) Debitor Pailit wajib hadir sendiri dalam rapat pencocokan piutang, agar dapat memberikan keterangan yang diminta oleh Hakim Pengawas mengenai sebab musabab kepailitan dan keadaan harta pailit dan ayat (2) Kreditor dapat meminta keterangan dari Debitor Pailit mengenai hal-hal yang dikemukakan melalui Hakim Pengawas. Dengan alasan-alasan tersebut debitor wajib ditahan

\footnotetext{
${ }^{14}$ Pasal 93 ayat (1),(2),(3),(4), UU No. 37 Tahun 2004 Tentang Kepailitan dan PKPU.
}

apabila debitor tidak melaksanakan ketentuan aturan tersebut.

Pengamanan dalam bentuk pengurusan, penguasaan dan pemberesan harta pailit oleh kurator merupakan tindakan preventif untuk mencegah jangan sampai harta kekayaan si pailit dialih tangankan kepada pihak lain yang tidak berhak. Berkenaan dengan hal itulah, maka kurator harus melakukan tindakan-tindakan sebagai berikut: ${ }^{15}$

1. Mengupayakan penyimpanan boedel debitor pailit, setelah diadakan pengamanan secukupnya, misalnya dibuatkan daftar inventarisasi, suratsurat berharga, uang tunai dan perhiasan berharga harus disimpan oleh BHP, kecuali ditentukan lain oleh hakim komisaris.

2. Mengupayakan penyegelan boedel bila dianggap perlu, tentunya penyegelan itu dilakukan oleh panitera Pengadilan Negeri dengan disaksikan oleh dua orang saksi.

3. Membuat daftar keuntungan dan kerugian yang menunjukan jumlah pasiva maupun aktiva,namanama dan tempat tinggal para kreditor,serta jumlah tagihan masing-masing.

4. Melanjutkan perusahan si pailit apabila dengan upaya itu dapat diharapkan bertambahnya jumlah aktiva dari perusahan. Pelanjutan perusahan itu memerlukan saran dari panitia para kreditor atau hakim komisaris apabila panitia tersebut tidak ada.

5. Menjual benda-benda debitor pailit (sebelum tahap insolvensi), bila benda-benda tersebut tidak tahan lama untuk disimpan. Hasil penjualan itu dipandang perlu, dapat dipakai untuk membiayai kepailitan.

6. Mengadakan akor setelah mendapat saran-saran dari Panitia Para Kreditor (kalau ada) serta mendapat persetujuan dari hakim komisaris.

7. Dapat melakukan pinjaman dari pihak ketiga semata-mata dalam rangka men ingkatkan harta pailit.

Penerapan paksa badan atau imprisonment for civil debt memberi kesan terjadinya intervensi hukum pidana sebagai bagian hukum publik terhadap masalah-masalah perdata (utang piutang). Hal ini dalam batas-batas tertentu dapat dibenarkan, mengingat sikap komplementer semacam itu juga tidakasing lagi dalam kehidupan hukum Indonesia. Sifat komplementer juga terjadi antara hukum

\footnotetext{
${ }^{15}$ Zainal Azikin. 2001. Hukum Kepailitan dan Penundaan Pembayaran Di Indonesia. Cet.Jakarta:PT.Raja Grafindo Persada. hlm. 51.
} 
pidana dan hukum administrasi, dalam bentuk Administrative Penal Law yang semakin marak dalam kehidupan modern. Sehubungan dengan hal ini tanpak semakin intesifnya kriminalisasi perbuatanperbuatan yang sebenarnya masuk dalam wilayah administrative. Dalam hal ini dibutuhkan sanksi pidana untuk memperkuat sanksi administrative dalam rangkaketaatan terhadap norma-normanya sebagai contoh dalam masalah lingkungan hidup, perpajakan, perlindungan konsumen dan sebagainya. Dengan perkembangan ini, meskipun agak aneh, tetapi atas dasar asas komplementer antara hukum perdata dan hukum pidana, pendayagunaan imprisonment yang merupakan sanksi hukum pidana, sebagai upaya pemaksa badan terhadap debitor yang beritikad tidak baik, penerapan lembaga ini masih dapat dibenarkan apabila didasarkan atas alasan yang dapat dipertanggung jawabkan. ${ }^{16}$

\section{Kewenangan Jaksa Melakukan Penahanan Menurut UU Kejaksaan}

Ketentuan Pasal 1 ayat (1) dalam UndangUndang Nomor 16 Tahu 2004 tentang Kejaksaan Republik Indonesia memberikan definisi Jaksa adalah pejabat fungsional yang diberi wewenang oleh undang-undang untuk bertindak sebagai penuntut umum dan pelaksana putusan pengadilan yang telah memperoleh kekuatan hukum tetap serta wewenang lain berdasarkan undang-undang. Kemudian ayat (2) Penuntut Umum adalah jaksa yang diberi wewenang oleh UndangUndang ini untuk melakukan penuntutan dan melaksanakan penetapan hakim dan ayat (4) Jabatan Fungsional Jaksa adalah jabatan yang bersifat keahlian teknis dalam organisasi kejaksaan yang karena fungsinya memungkinkan kelancaran pelaksanaan tugas kejaksaan.

Pasal 30 ayat (1) Di bidang pidana, kejaksaan mempunyai tugas dan wewenang:

a. melakukan penuntutan;

b. melaksanakan penetapan hakim dan putusan pengadilan yang telah memperoleh kekuatan hukum tetap;

c. melakukan pengawasan terhadap pelaksanaan putusan pidana bersyarat, putusan pidana pengawasan, dan keputusan lepas bersyarat;

d. melakukan penyidikan terhadap tindak pidana tertentu berdasarkan undang- undang.

\footnotetext{
${ }^{16}$ Muladi. 2002. Analisa Gijzeling dari Sisi Hukum Pidana dan HAM. Artikel dalam Jurnal Hukum Bisnis Vol.XIhlm. 25. Di akses 19 Mei 2019.
}

\section{Kewenangan Jaksa Melakukan Penahanan Menurut UU KUHAP}

Pasal 13 KUHAP memberikan pejelasan bahwa Penuntut umum adalah jaksa yang diberi wewenang oleh undang-undang ini untuk melakukan penuntutan dan melaksanakan penetapan hakim. Pasal 14 Penuntut umum diberi kewenangan yaitu:

a. menerimadanmemeriksaberkasperkarapenyidikan dari penyidik atau penyidik pembantu;

b. mengadakan prapenuntutan apabila ada kekurangan pada penyidikan dengan memperhatikan ketentuan Pasal 110 ayat (3) dan ayat (4), dengan memberi petunjuk dalam rangka penyempurnaan penyidikan dari penyidik;

c. memberikan perpanjangan penahanan, melakukan penahanan atau penahanan lanjutan dan atau mengubah status tahanan setelah perkaranya dilimpahkan oleh penyidik;

d. membuat surat dakwaan;

e. melimpahkan perkara ke pengadilan;

f. menyampaikan pemberitahuan kepada terdakwa tentang ketentuan hari dan waktu perkara disidangkan yang disertai surat panggilan, baik kepada terdakwa maupun kepada saksi, untuk datang pada sidang yang telah ditentukan; melakukan penuntutan;

g. menutup perkara demi kepentingan hukum;

h. mengadakan tindakan lain dalam lingkup tugas dan tanggung jawab sebagai penuntut umum menurut ketentuan undang-undang ini;

i. melaksanakan penetapan hakim.

\section{Kewenangan Jaksa Melakukan Penahanan Menurut UU 37 Tahun 2004}

Tindakan Pengurusan dan penguasaas harta bendanya berada pada kurator. Akan tetapi bila menyangkut harta benda yang akan diperolehnya debitor tetap dapat melakukan perbuatan hukum menerima harta benda yang akan diperolehnya itu namun harta yang diperolehnya itu menjadi bagian harta pailit. ${ }^{17}$ Kepailitan berakibat terhadap harta kekayaan debitor, menurut Undang-Undang Kepailitan Nomor 37 Tahun 2004 Pasal 93 terhadap debitor juga dapat dikenakan Penahanan debitor.

\footnotetext{
17 Sutan Remy Sjahdeini. 2002.Hukum Kepailitan Memahami Faillissementsverordoning juncto Undang-Undang No 4 Tahun 1998:, Jakarta: Pustaka Utama Grafiti. hlm. 257
} 
Tindakan penahanan debitor dapat diusulkan hakim pengawas, permintaan kurator,atau atas permintaan seorang kreditor atau lebih setelah mendengar hakim pengawas pengadilan dalam putusan pernyataan pailit atau setiap waktu setelah itu dapat memerintahkan supaya debitor pailit di tahan dibawah pengawasan jaksa yang ditunjuk oleh hakim pengawas . Adapun bunyi pasal 93 Undang-Undang Nomor 37 Tahun 2004 adalah:

1. Pengadilan dengan putusan pernyataan pailit atau setiapwaktusetelahitu, atasusul Hakim Pengawas, permintaan Kurator, atau atas permintaan seorang Kreditor atau lebih dan setelah mendengar Hakim Pengawas, dapat memerintahkan supaya Debitor Pailit ditahan, baik ditempatkan di Rumah Tahanan Negara maupun di rumahnya sendiri, di bawah pengawasan jaksa yang ditunjuk oleh Hakim Pengawas.

2 Perintah penahanan sebagaimana dimaksud pada ayat (1) dilaksanakan oleh jaksa yang ditunjuk oleh Hakim Pengawas

3. Masa penahanan sebagaimana dimaksud pada ayat (2) berlaku paling lama 30 (tiga puluh) hari terhitung sejak penahanan dilaksanakan.

4. Padaakhirtenggangwaktusebagaimanadimaksud pada ayat (3), atas usul Hakim Pengawas atau atas permintaan Kurator atau seorang Kreditor atau lebih dan setelah mendengar Hakim Pengawas, Pengadilan dapat memperpanjang masa penahanan setiap kali untuk jangka waktu paling lama 30 (tiga puluh) hari.

5. Biaya penahanan dibebankan kepada harta pailit sebagai utang harta pailit.

Permintaan untuk menahan Debitor Pailit harus dikabulkan, apabila permintaan tersebut didasarkan atas alasan bahwa Debitor Pailit dengan sengaja tidak memenuhi kewajiban sebagaimana dimaksud dalam Pasal 98, Pasal 110, atau Pasal 121 ayat (1) dan ayat (2).

Ketentuan 93 yang mengatur tentang Penahanan terhadap debitor ini tidaklah jauh berbeda dengan undang-undang Kepailitan terdahulu yaitu Undang-

Undang Nomor 4 Tahun 1998 tentang Kepailitan yang dikenal dengan istilah Penyanderaan atau paksa badan. Masalah ini diatur dalam pasal 84 UndangUndang Nomor 4 Tahun 1998 tentang Kepailitan yang menentukan bahwa (1) Pengadilan Niaga dalam putusan pernyataan pailit atau pada waktu setelah itu dapat melakukan penahanan terhadap debitor, tetapi dalam hal terakhir hanya dilakukan atas usul hakim

komisaris atau permintaan seorang atau beberapa kreditor setelah mendengar Hakim Komisaris, baik dalam penjara maupundirumah tahanan atau dirumah seorang kreditor dengan diawasi pegawai penguasa umum. (2) Perintah dalam ayat (1) tersebut dijalankan oleh penuntutumum (3)Perintah tersebut tidak berlaku untuk lebih tigapuluh hari terhitung dari harimulainya perintah itu dilaksanakan. Pada akhir tenggang waktu tersebut atau atas usul Hakim Komisaris atau atas permintaan, dan setelah mendengar seperti yang dimaksud dalam ayat (1) tersebut diatas, Pengadilan Negeri dapat memperpanjang perintah untuk jangka waktu paling lama tiga puluh hari. Setelah itu dapat pula hal yang sama dilakukan untuk paling lama tiga puluh hari. Menurut Sutan Remy Sajhdenini terdapat beberapa kelemahan yaitu: ${ }^{18}$

1. Ketentuan tentang Penerapan lembaga penahanan dalam Undang-Undang Nomor 37 Tahun 2004 tentang Kepailitan dan PKPU yang mengatur tentang penahanan debitor dalam kepailitan tidak terdapat ketentuan yang mengatur dalam hal apa saja penahanan terhadap debitor pailit itu dapat diperintahkan oleh hakim pengawas .Penjelasan Pasal 93 tidak memberikan keterangan apapun agarpelaksanaanlembagapenahanandebitorpailit tersebut tidak di salah gunakan dan menimbulkan praktek praktek tidak sehat, yang seyogjanya ditentukan secara limitif alasan-alasan apa saja yang dapat dijadikan bahan pertimbangan untuk mengajukan usul pertimbangan penahanan oleh hakim pengawas, atau alasan untuk mengajukan permintaan oleh kurator atau oleh kreditor kepada pengadilan agar debitor ditahan. Alasan-alasan itu dapat dijadikan alasan bagi Pengadilan Niaga untuk mengabulkan atau menolak usul atau permohonan agar pailit ditahan,

2. Batas waktu jangka penahanan, dimana pasal 93 ayat 4 pada akhir tenggang waktu tersebut atas usul hakim pengawas, pengadilan niaga dapat memperpanjang masa penahanan itu untuk setiap kali untuk jangka waktu paling lama paling lama 30 hari. Dengan demikian masa penahanan dapat berkepanjangan karena sekalipun setiap 30 hari masa penahanan itu berakhir tetapi selalu dapat dimintakan perpanjangan untuk 30 hari lagi.

3. Pasal 95 yang menentukan permintaan untuk penahanan debitor pailit harus di kabulkan, apabila permintaan tersebut didasarkan alasan bahwa debitor pailit dengan sengaja tidak memenuhi kewajiban sebagaimana yang dimaksud dalam Pasal 98, Pasal 110 atau Pasal 121 ayat (1) dan 
(2). Ketentuan Pasal 95 yang menunjuk Pasal 98 sangat menimbulkan pertanyaan, karena Pasal 98 tidak berisi kewajibanan yang harus dipenuhi debitor, tetapi berisi kewajiban bagi kurator. Jadi bagaimana debitor bisa dikatakan melanggar pasal tersebut sebagai alasan penahanannya. Keharusan bagi pengadilan niaga untuk mengabulkan permintaan penahanan sebagaimana yang dimaksud dalam Pasal 95 tersebut yaitu dalam hal debitor pailit tidak memenuhi kewajiban pasal 110 dan pasal 121 adalah apabila dapat dibuktikan bahwa debitor pailit dengan sengaja tidak memenuhi kewajiban yang ditentukan oleh dua pasal tersebut. Namun demikian apabila tidak terpenuhinya kewajiban debitor pailit tersebut bukan karena sengaja, bukan berarti pengadilan harus menolak permohonan penahann tersebut. Hal ini terjadi karena Undang-Undang Nomor 37 Tahun 2004 tentang Kepailitan dan PKPU tidak menentukan alasan-alasan yang bersifat limitif dalam hal apa saja seorang debitor pailit dapat diputuskan oleh pengadilan untuk ditahan, maka hakim bebas untuk mengabulkan atau menolak permohonan tersebut. Dengan kata lain dapat saja hakim mengabulkan permohonan tersebut sekalipun tidak melanggar kewajiban debitor pailit yang ditentukan Pasal 110 dan Pasal 121 tetapi memutuskan menahan debitor pailitkarena pertimbangan lain.

Penerapan lembaga penahan atau paksa badan terhadap debitor harus jelas alasan-alasan dan kreteria debitor yang dapat diterapkan penahanan atau paksa badan. Jangan sampai adanya ketentuan tersebut menjadi peluang bagi pihak-pihak tertentu untuk melakukan penahanan terhadap debitor, dan satu hal yang perlu diingat bahwa debitor yang dipailitkan terdiri dari debitor yang memang tidak mampu membayar utang-utangnya dan ada juga debitoryang beritikad buruk. ${ }^{19}$

\section{Pengaturan Penahanan dalam Ketentuan Undang-Undang Nomor 37 tahun 2004}

KUHAP dalam Pasal 1 butir 21 menyebutkan Penahanan adalah penempatan tersangka atau terdakwaditempattertentuolehpenyidikataupenuntut umum atau hakim dengan penetapannya dalam hal serta menurut cara yang diatur dalam KUHAP sedangkan ketentuan dalam Undang-Undang Nomor 37 Tahun 2004 tidak memberikan definisi mengenai penahanan, tetapi hanya menentukan tempat Debitor Pailit ditahan, baik di Rumah Tahanan Negara maupun di rumahnya sendiri, di bawah pengawasan jaksa yang ditunjuk oleh hakim pengawas. KUHAP memberikan alasan dilakukannya penahanan, yaitu adanya kekhawatiran bahwa tersangka/terdakwa akan melarikan diri, menghilangkan atau merusak barang bukti, dan/atau mengulangi tindak pidana. Seperti halnya ketentuan yang diatur dalam KUHAP mengenai alasan seseorang ditahan, Undang- Undang Nomor 37 Tahun 2004 tentang Kepailitan dan PKPU terkait kurator harus diberikan semua daftar serta dokumen mengenai aset yang dimiliki oleh debitor pailit. Kemudian mewajibkan Debitor Pailit menghadap Hakim Pengawas, Kurator, atau panitia kreditor apabila dipanggil untuk memberikan keterangan. Debitor Pailit wajib hadir sendiri, guna memberikan keterangan yang diminta oleh Hakim Pengawas mengenai sebab musabab kepailitan dan keadaan harta pailit, Kreditor dapat meminta keterangan dari Debitor Pailit mengenai hal-hal yang dikemukakan melalui Hakim Pengawas. Debitor dapat ditahan apabila tidak melaksanakan tidak melaksanakan ketentuan aturan tersebut. Keterangan atau informasi berkaitan dengan harta pailit inilah yang merupakan alat bukti yang dikhawatirkan akan disembunyikan oleh debitor atau bahkan debitor pailit berupaya melarikan diri karena tidak mau memberikan keterangan terkaitharta pailit (boedel pailit) Penerapan penahanan (paksa badan) atau imprisonment for civil debt ini memberi kesan terjadinya intervensi hukum pidana sebagai bagian hukum publik terhadap masalah-masalah perdata (utang-piutang). Hal ini dalam batas-batas tertentu dapat dibenarkan hanya saja untuk pelaksanaanya, hanya saja berdasarkan hasil rapat pleno kamar Mahkamah Agung Republik Indonesia Tahun 2012 beberapa usulan terhadap debitor yang tidak kooperatif untuk dikenakan paksa badan tidak dapat dilaksanakan secara efektif, baik sebagai implementasi dari Pasal 84 Undang-Undang Nomor 4 Tahun 1998 maupun maupun Peraturan Mah-kamah Agung Nomor

1 Tahun 2000 dikarenakan belum ada perangkat hukum dan peraturan pelaksanaan Undang-Undang No 37 Tahun 2004 mengenai penahanan debitor pailit dalam hal biaya, prosedur dan kerjasama dengan instansi terkait sehingga belum ada satupun penahanan (ginzeling) yang ditetapkan pengadilan Niaga. 


\section{Kewenangan Jaksa dalam Melakukan Penahanan Debitor Pailit}

Penahanan merupakan salah satu bentuk perampasan kemerdekaan seseorang. Oleh karena itu, seharusnyapenahanandilakukandenganalasan-alasan yang diatur dalam peraturan perundang-undangan. Dalam KUHAP, penahanan dilakukan kerena Adanya kekhawatiran bahwa tersangka atau terdakwa akanmelarikan diri, merusak / menghilangkan barang bukti dan / atau mengulangi tindak pidana. Kesalahan atau kekeliruan dalam penahanan dapat dilakukan upaya Praperadilan. Selain itu, penahanan harus dilakukan oleh Instansi yang berwenang untuk melakukan penahanan. Ketentuan dalam HIR, instansi yang berwenang melakukan penahan adalah Jaksa dan Pembantu Jaksa dan hakim hanya melakukan perpanjangan penahanan yang dilakukan oleh Jaksa, sedangkan ketentuan Penahanan dalam KUHAP terdapat tiga instansi yang berwenang melakukan penahanan, yaitu penyidik atau penyidik pembantu, penuntut umum dan hakim berdasarkan tingkat pemeriksaan terdiri dari hakim Pengadilan Negeri, Pengadilan Tinggi dan Mahakamah Agung.

UU Kepailitan mengatur tentang penahanan debitor pailit, dimana Penahanan debitor pailit dilaksanakan oleh Jaksa yang ditunjuk oleh Hakim Pengawas. UU Kepailitan tidak mengatur mekanisme penahanan oleh Jaksa yang ditunjuk oleh Hakim Pengawas secara rinci. Adapun menurut UU Kejaksaan, bahwa yang dimaksud dengan Jaksa adalah pejabat fungsional yang diberi wewenang oleh undang-undang untuk bertindak sebagai penuntut umum dan pelaksanaan putusan pengadilan yang telah memperoleh kekuatan hukum tetap serta wewenang lain berdasarkan undang-undang. Dengan demikian Jaksa berwenang melakukan penahanan terhadap debitor pailit. Menjadi permasalahan kemudian apakah Hakim Pengawas mempunyai kewenangan untuk memerintahkan Jaksa. Hakim pengawas, atas perintah pengadilan dapat menunjuk jaksa untuk melakukan penahanan terhadap Debitor Pailit. Kewenangan hakim pengawas ini merupakan kewenangan delegasi dari pengadilan. Sehingga penunjukan Jaksa yang dilakukan oleh hakim pengawas dapat ditafsirkan sebagai penetapan pengadilan utuk memerintahkan penahanan oleh Jaksa. Sedangkan yang dimaksud dengan Jaksa yang ditunjuk oleh hakim pengawas adalah jaksa pada kejaksaan negeri yang wilayah kerjanya berdasarkan domisili debitor itu berada.

\section{Kesimpulan dan Saran}

Alasan Penahanan yang ditentukan oleh KUHAP dapat disamakan dengan alasan penahanan yang ditentukan oleh Undang-Undang Nomor 37 Tahun 2004 tentang Kepailitan dan PKPU mengenai di khawatirkannya Debitor pailit atau tersangka melarikan diri, menghilangkan barang bukti, yang dapat merugikan kepentingan banyak pihak, dalam hal ini informasi yang dimiliki serta kewajiban memberikan informasi oleh debitor pailit mengenai keberadaan aset yang menjadi harta pailit kepaad Kurator, Hakim Pengawas maupun panitia rapat kreditor. Tetapi tidak adanya pengaturan mengenai aturan pelaksanaan terkait penahanan yang dimaksud dalam Undang- Undang Nomor 37 Tahun 2004 dan PKPU sampai saat ini sehingga belum ada satupun penahanan (ginzeling) yang ditetapkan pengadilan Niaga.

Undang-Undang Nomor 37 Tahun 2004 tentang Kepailitan dan PKPU tidak mengatur mekanisme penahanan oleh Jaksa yang ditunjuk oleh Hakim Pengawas secara rinci, Hakim pengawas, atas perintah pengadilan dapat menunjuk jaksa untuk melakukan penahanan terhadap Debitor Pailit. Kewenangan hakim pengawas ini merupakan kewenangan delegasi dari pengadilan. Sehingga penunjukan Jaksa yang dilakukan oleh hakim pengawas dapat ditafsirkan sebagai penetapan pengadilan utuk memerintahkan penahanan oleh Jaksa. Sehingga yang di tunjuk oleh Hakim Pengawas adalah jaksa pada kejaksaan negeri yang wilayah kerjanya berdasarkan domisili debitor itu berada.

Perlu dibuatkan aturan pelaksanaan terkait penahanan yang dimaksud dalam Undang- Undang Nomor 37 Tahun 2004 dan PKPU yang memuat dengan tegas dan rinci mengenai alasan dan jenis debitor yang dapat ditahan.

Perlu aturan pelaksanaan yang mengatur mekanisme penahanan oleh Jaksa yang ditunjuk oleh Hakim Pengawas secara rinci, agar tidak terjadi permasalahan mengenai kewenangan jaksa mana yang berwenang melakukan penahanan sesuai dengan amanat UndangUndang Nomor 37 Tahun 2004 tentang Kepailitan dan PKPU. 


\section{Daftar Pustaka}

Berlian Simarmata, Pengawasan Terhadap Pelaksanaan Penahanan Menurut Kuhap Dan Konsep Ruu Kuhap, Mimbar Hukum Volume 23, Nomor 1, Februari 2011, Halaman 1 - 236.

Djoko Prakoso, 1985, Eksistensi Jaksa di Tengah- Tengah Masyarakat, Ghalia Indonesia, Jakarta.

L. Sumartini, 1996, Pembahasan Perkembangan Pembangunan Hukum Nasional tentang Hukum Acara Pidana, BPHN Depkeh dan HAM RI.

Mabes Polri, 2000, Himpunan Bujuklak, Bujuklap, Bujukmin Proses Penyidikan Tindak Pidana, Departemen Hankam, Mabes Polri, Jakarta.

M. Hadi Subhan, 2015, Hukum Kepailitan, Prinsip Norma dan Praktik di Peradilan, Kecana Prenadamedia Group, Jakarta.

Muladi. 2002. Analisa Gijzeling dari Sisi Hukum Pidana dan HAM. Artikel dalam Jurnal Hukum Bisnis Vol.XIhlm. 25. Di akses 19 Mei 2019.

Mulyasi W. Gizeling dalam Perkara Pajak, http:// eprints.undip.ac.id /15739 /1 / Mulyatsih_ Wahyumurti.pdf, akses tanggal 19 Mei 2019.

M. Yahya Harahap, 2003, Pembahasan Permasalahan dan Penerapan KUHAP, Penyidikan dan Penuntutan, Sinar Grafika, Jakarta.

H. M. A. Kuffal, 2007, Penerapan KUHAP dalam Praktik Hukum, UMM Press, Malang.

Sutan Remy Sjahdeini. 2002. Hukum Kepailitan Memahami Faillissements verordoning juncto UndangUndang No 4 Tahun 1998, Jakarta: Pustaka Utama Grafiti.

Zainal Azikin. 2001. Hukum Kepailitan dan Penun- daan Pembayaran Di Indonesia. Jakarta:PT.Raja Grafindo Persada.

\section{Undang-Undang}

Undang Undang No. 8 Tahun 1981 Tentang Kitab Undang Undang Hukum Acara Pidana

Undang-Undang No. 4 Tahun 1998 Tentang Kepa- ilitan dan Penundaan Kewajiban Pembayaran Utang Undang-Undang No. 37 Tahun 2004 Tentang Kepailitan dan Penundaan Kewajiban Pembayaran Utang Peraturan Mahkamah Agung RI No.1 Tahun 2000 Tentang Paksa Badan 